Note

\section{Increased Insulin Binding by Erythrocytes from Rat Fetus}

\section{Yutaka WAKo and Suichi KIMURA}

\author{
Laboratory of Nutrition, \\ Department of Food Chemistry, Faculty of Agriculture, \\ Tohoku University, Sendai 980, Japan
}

Received January 27, 1984

Pancreatic insulin has been detected in the fetal rat as early as the 14th day of gestation and its concentration increases rapidly to a maximum at the 18 th day. ${ }^{1)} \mathrm{A}$ number of studies have suggested that insulin in the fetus palys an important role in fetal growth or metabolism, but this is still uncertain. ${ }^{2,3)}$ To understand the action of insulin on cells, the properties of receptors for insulin should be investigated. However, few such detailed studies of fetal receptors have been carried out. Concerning the rat fetus, the properties of insulin receptors of livers and lungs were examined ${ }^{4,5}$ but studies of receptors on circulating cells have not been done. Consequently we studied the properties of insulin receptors of erythrocytes obtained from rat fetuses and compared them with those obtained from fetuses of diabetic pregnant rats and adult rats with a view to investigate the role of fetal insulin. The biological effects of insulin on circulating monocytes have already been shown. ${ }^{6)}$ It has also been demonstrated that the changes in insulin receptors on monocytes reflect changes in receptors on other cells. ${ }^{7)}$ On the other hand the biological significance of insulin receptors on the circulating erythrocytes remains unclear. In the present paper we used erythrocytes for our insulin binding study while keeping in mind the fact that insulin receptors on the erythrocytes during diabetes change in the same way as those on the monocytes. ${ }^{8)}$

Virgin female Wistar rats weighing $250 \pm 50 \mathrm{~g}$ were divided in two groups. One group was injected intraperitoneally with streptozotocin $(45 \mathrm{mg} / \mathrm{kg}$ of body weight, the Sigma Chemical Co., Lot No. 31F-0130) dissolved in citrate buffer $(0.01 \mathrm{M}, \mathrm{pH} 4.0)$. Normal and diabetic virginal rats were mated. Pregnant rats (22nd day of gestation) were sacrificed by decapitation and the fetuses removed by caesarian section. Blood samples from litter mates were pooled. Samples from adult male rats served as controls. The preparation of erythrocytes and our binding study were carried out by the method of Gambhir et $a .^{9)}$ Erythrocytes were purified and resuspended in "assay buffer" (50 mM Hepes, $50 \mathrm{~mm}$ Tris, $10 \mathrm{mM} \mathrm{MgCl}_{2}$, $2 \mathrm{~mm}$ EDTA, $10 \mathrm{~mm}$ glucose, $10 \mathrm{~mm} \mathrm{CaCl}_{2}, 50 \mathrm{~mm} \mathrm{NaCl}$, $5 \mathrm{~mm} \mathrm{KCl}$ and $0.1 \%$ bovine serúm albumin, $\mathrm{pH} 8.0$ ). Table I shows the mean cell concentration, hematocrit, and hemoglobin levels for the suspensions which were used for the binding study. Binding of $\left[{ }^{125} \mathrm{I}\right]$ insulin (New England Nuclear, NEX-104 $100.2 \mu \mathrm{Ci} / \mu \mathrm{g}$ ) to erythrocytes was determined by incubating a $150 \mu \mathrm{l}$ cell suspension, $125 \mathrm{pg}$ of $\left[{ }^{125} \mathrm{I}\right]$ insulin (in $50 \mu \mathrm{l}$ of buffer) and unlabeled insulin ( 0 to $4 \times 10^{3} \mathrm{ng}$, the Sigma Chemical Co., I-5500 $\left.25.5 \mathrm{IU} / \mathrm{mg}\right)$. After incubation at $15^{\circ} \mathrm{C}$ for $2 \mathrm{hr}, 200 \mu \mathrm{l}$ of the incubated suspension was put into prechilled tubes each containing $200 \mu \mathrm{l}$ of assay buffer. The cells were sedimented and separated from the assay buffer. The radioactivity in each cell pellet was counted in a gamma counter (Shimadzu Seisakusho LTD. AL-201B). Radioactivity found in cells in the presence of $10 \mu \mathrm{g} / \mathrm{ml}$ of unlabeled insulin was considered as "nonspecific" binding and was subtracted from the total binding. The data from the binding studies normalized to $1.8 \times 10^{9}$ erythrocytes per $\mathrm{ml}$ were subjected to Scatchard analysis. ${ }^{10)}$ Concentrations of bound insulin (B) were calculated from bound radioactivity and the free concentration $(\mathrm{F})$ was calculated by subtracting $\mathrm{B}$ from the total insulin concentration. A plot of $B / F$ to $B$ was constructed. The $\mathrm{X}$ intercept of the terminal slope of this plot (three to four) gives the maximal amount of insulin bound.

Figure 1(A) is a Scatchard analysis of the binding data for fetuses of normal and diabetic pregnant rats, and adult rats. These analysis resulted in a curve with a upward concave configuration and approximately agreed with the theoretical Scatchard plots for ligand binding to a single class of sites with negative cooperativity. The maximum amount of insulin bound per $1.8 \times 10^{9}$ erythrocytes is approximately $1.4 \times 10^{-11} \mathrm{~mol}$ for normal fetuses, $2.5 \times$ $10^{-11}$ mol for fetuses of diabetic pregnant rats, and $8.2 \times$ $10^{-12} \mathrm{~mol}$ for adult rats. Figure $1(\mathrm{~B})$ shows the average affinity profiles according to DeMeytes et al. ${ }^{11)}$ The affinity constant at tracer concentrations of insulin is $1.52 \times$

TABle I. INDEXES OF Cell SuSPENSION FOR BINDING STUDY

\begin{tabular}{lccc}
\hline & Normal fetus & Diavetic $^{a}$ & Adult rat \\
\hline $\begin{array}{c}\text { Cell number } \\
\left(\times 10^{9} / \mathrm{ml}\right)\end{array}$ & $3.1 \pm 0.8$ & $2.8 \pm 0.2$ & $8.2 \pm 1.3^{*}$ \\
$\begin{array}{c}\text { Hematocrit } \\
(\%)\end{array}$ & $36.3 \pm 2.5$ & $32.5 \pm 2.5$ & $41.7 \pm 2.9^{*}$ \\
$\begin{array}{c}\text { Hemoglobin } \\
(\mathrm{g} / 100 \mu \mathrm{l})\end{array}$ & $10.8 \pm 0.5$ & $9.3 \pm 1.9$ & $14.5 \pm 1.4^{*}$ \\
$\mathrm{MCV}^{b}$ \\
$(\mu)$ \\
$\begin{array}{c}\mathrm{MCH}{ }^{c} \\
(\mathrm{pg})\end{array}$ & $37.6 \pm 8.0$ & $33.5 \pm 4.9$ & $17.9 \pm 1.3^{*}$ \\
\hline
\end{tabular}

a Fetus of diabetic pregnant rat. Values are mean \pm S.D. of duplicate determinations of three litter mates or three rats.

$b$ Mean corpuscular volume.

c Mean corpuscular hemoglobin. Significantly different from normal fetus, ${ }^{*} p<0.005$. 

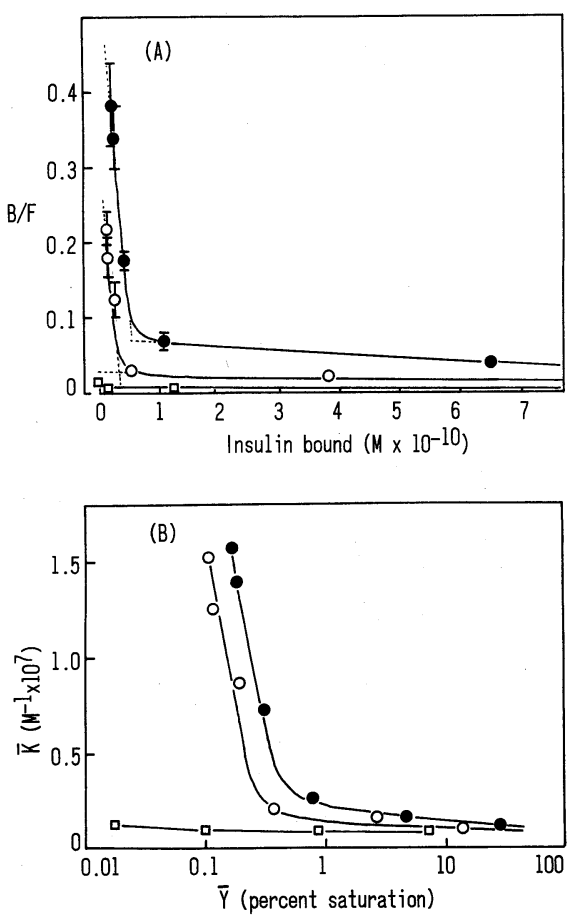

FIG. 1. Scatchard Plot (A) of Insulin Binding to Erythrocytes of Normal Fetuses ( $O$ ), Fetuses of Diabetic Pregnant Rats (O), and Adult Rats ( $\square$ ).

All data were normalized to $1.8 \times 10^{9}$ erythrocytes and represent the mean of duplicate studies of three pools. Average affinity profiles (B) for normal fetuses ( $\bigcirc$ ), fetuses of diabetic pregnant rats $(O)$, and adults rats $(\square)$ calculated from data in (A).

$10^{7} \mathrm{M}^{-1}$ for normal fetuses, $1.57 \times 10^{7} \mathrm{M}^{-1}$ for fetuses of diabetic pregnant rats, and $1.64 \times 10^{6} \mathrm{M}^{-1}$ for adult rats.

This experiment demonstrated that erythrocytes from fetuses had markedly increased binding capacity for insulin compared with those from adults. Probably this increased binding capacity was caused by the large size of erythrocytes (macrocytes) in the fetus (Table I). Some studies also suggested that fetuses at term had a greater binding capacity for insulin. ${ }^{4,12)}$ Consequently, fetal tissues seemed to be fully sensitive to insulin, whereas the insulin response to glucose uptake and glucose utilization have been revealed to be blunt in rat fetal diaphragm. ${ }^{13,14)}$ Thorsson and Hintz suggested that findings of high concentrations of high affinity receptors for insulin on fetal monocytes supports the hypothesis that insulin may be a "growth hormone" in fetuses. Anyway, inslulin in the fetus may have an important role in intrauterine growth and development.

The fetuses of diabetic pregnant rats had significantly higher serum glucose and IRI (immunoreactive insulin) levels than normal fetuses $(213.0 \pm 85.0 \mathrm{mg} / \mathrm{dl} v s .66 .0 \pm$ $7.8 \mathrm{mg} / \mathrm{dl}, \quad 127.8 \pm 13.1 \mu \mathrm{U} / \mathrm{ml}$ vs. $90.5 \pm 19.8 \mu \mathrm{U} / \mathrm{ml})$.
We tried to compare the insulin binding ability of erythrocytes in normal fetuses and fetuses of diabetic pregnant rats. Although the $B / F$ ratio was increased in fetuses of diabetic pregnant rats at various amounts of bound insulin, we could not find a distinct difference in the binding capacity between them (Fig. 1A). We also could not find a difference in their affinity constants (Fig. 1B). To find whether erythrocytes from fetuses of diabetic pregnant rats have a greater binding ability, further detailed studies are needed. Neufeld et al. showed that monocytes from infants of gestational diabetic mothers (IGDM) and markedly increased ability to bind insulin. ${ }^{15)}$ The mechanisms responsible for this increased insulin binding ability in IGDM are not clear. It has been shown that increased numbers of insulin receptors paralleled increased insulin concentrations in the fetal pancreas. ${ }^{16)}$ So it is possible that hyperinsulinism contributes to increases in insulin binding capacity in IGDM. These observation may suggest that diabetes in mothers affects the development of fetal insulin receptors.

In the present study, we found that erythrocytes from rat fetuses have increased binding capacity for insulin. This increased binding was due to the large size of erythrocytes in the fetuses.

\section{REFERENCES}

1) T. A. I. Grillo. Endocrinology, 31, 67 (1964).

2) L. Picon, Endorinology, 81, 1419 (1967).

3) J. D. Baird and J. W. Farquhar, Lancet, 1, 71 (1962).

4) N. D. Neufeld, M. Scott and S. A. Kaplan, Develop. Biol., 78, 151 (1980).

5) N. D. Neufeld and S. A. Kaplan, Diabetes, 28, 346 (1979).

6) T. B. Strom, R. A. Bear and C. B. Carpenter, Science, 187, 1206 (1975).

7) J. M. Olefsky, J. Clin. Invest., 57, 1162 (1976).

8) Y. Oka, Clinical Endocrinology, 29, 23 (1981).

9) K. K. Gambhir, J. A. Archer and C. J. Bradley, Diabetes, 27, 701 (1978).

10) G. Scatchard, Ann. New York Acad. Sci., 51, 660 (1949).

11) P. DeMeyts and J. Roth, Biochem. Biophys. Res. Commun., 66, 1118 (1975).

12) A. Thorsson and R. L. Hintz, New Engl. J. Med., 297, 908 (1977).

13) F. Robert and C. M. Clark, Jr., Am. J. Physiol., 224, 117 (1973).

14) H. G. Britton and M. Blade, Biol. Neonate, 16, 370 (1970).

15) N. D. Neufeld, S. A. Kaplan, B. M. Lippe and M. Scott, J. Clin. Endoclinol. Metab., 47, 590 (1978).

16) R. Pictet and W. J. Rutter, "Development of the Embryonic Pancreas," Handbook of Physiology, Sect. 7, Endocrinology, Vol. 1, Williams and Wilkins, Baltimore, 1972. 